\title{
TINJAUAN TEORITIS: SELF REGULATION PADA MAHASISWA UNDERACHIEVER
}

\author{
Nangoi Priscilla Francis \\ Jurusan Psikologi, Fakultas Psikologi, Bina Nusantara University \\ Jln. Kemanggisan Ilir III No. 45, Kemanggisan, Palmerah, Jakarta Barat 11480 \\ Priscilla@binus.edu
}

\begin{abstract}
Self regulation is needed by every individual as a description of their ability to control themselves. Not every individual has good self regulation such as students categorized as underachievers. Self regulation on underachiever students could be said to be lower than high achiever students. There are many factors contributing to low self regulation, such as lack of responsibility towards personal goals, even personal goals that may be set by someone else.This theoretical review is anticipated to help realizing conditions that is happening towards ourselves and what is the factor behind it. Parents and educators may also understand the treatment causing children to have low self regulation and becoming an underachiever.
\end{abstract}

Keywords: underachiever, self regulation, parent

\begin{abstract}
ABSTRAK
Self regulation dibutuhkan setiap orang sebagai gambaran kemampuan sesorang untuk melakukan kontrol terhadap diri untuk mencapai tujuan yang diinginkan.Namun tidak semua orang memiliki Self regulation baik. Seperti pada mahasiswa dengan prestasi yang digolongkan sebagai underachiever. Self regulation pada mahasiswa underachiever bisa dikatakan lebih rendah daripada mahasiswa yang high achiever. Banyak hal yang menjadi efek dari memiliki self regulation kurang baik, seperti misalnya tanggung jawab terhadap tujuan diri yang kurang, bahkan mungkin merasa bahwa tujuan diri ditentukan oleh orang lain. Tinjauan teoritis ini diharapkan dapat membantu untuk menyadari kondisi yang terjadi pada diri kita saat ini dan apa yang menyebabkannya. Selain itu juga bagi para orang tua dan pendidik, sehingga mengetahui perlakuan yang dapat menyebabkan seorang anak memiliki self regulation rendah dan menyebabkan prestasi mereka tidak maksimal.
\end{abstract}

Kata kunci: underachiever, self regulation, orang tua 


\section{PENDAHULUAN}

Ketika kita membicarakan mengenai prestasi akademik, maka kita akan membagi prestasi tersebut menjadi tiga kategori yaitu rendah, sedang, dan tinggi. Setiap orang berharap dirinya termasuk dalam kategori prestasi yang tinggi/high achiever. Banyak hal yang positif yang selalu dikaitkan dengan orang-orang yang high achiever ini, seperti misalnya rajin, membanggakan, punya masa depan yang baik, orang yang gigih, pintar, berbakat, dan lain-lain. Bahkan bukan hanya yang melekat pada diri individu tersebut, namun juga orang-orang disekitarnya pun dianggap memiliki pengaruh terhadap pencapaian orang tersebut, seperti misalnya orang tuanya berarti pandai mendidiknya, guru/ dosennya berhasil mengajarkannya, keluarganya berhasil mendidik anak, dan lain sebagainya. Seringkali kita mendengar istilah buah jatuh tidak jauh dari pohonnya. Hal inilah gambaran ketika kita mengkaitkan atribut yang dimiliki seseorang dengan lingkungan sekitarnya. Kondisi ini tidak hanya terjadi pada high achiever atau middle achiever yang memiliki sambutan yang positif tadi. Pada siswa ataupun mahasiswa bahkan pekerja yang dengan prestasi kerja rendah/ underachiever, kondisi itu pun terjadi. Mungkin pernah dalam kehidupan kita, kita mengatakan kepada orang lain yang memiliki prestasi rendah bahwa mereka itu malas, bodoh, tidak memiliki motivasi, tidak memiliki harapan untuk masa depan yang baik, orang tuanya tidak mampu mendidik, dan lain sebagainya. Namun, pernahkah benarbenar dianalisa, mengenai bagaimana sebenarnya seseorang dapat menjadi underachiever? Apakah memang adalah kemampuan anak tersebut yang kurang baik, atau memang ada pengaruh dari pola asuh orang tua, ataukah sistem pendidikannya, ataukah dari pengaruh-pengaruh media, dan lain sebagainya. Hal inilah yang seringkali menjadi pertanyaan orang tua kepada pihak akademisi dimana anak mengenyam pendidikannya. "Apa yang harus saya lakukan supaya anak saya bisa kuliah dengan benar?” atau “Apa yang menyebabkan anak saya nilainya rendah?”. Pertanyaan-pertanyaan ini adalah pertanyaan yang biasa diungkapkan orang tua ketika bertemu dengan pihak institusi pendidikan baik dari jenjang TK, SD, SMP, SMA, bahkan juga Pergutuan Tinggi.

Terdapat banyak faktor yang memberikan kontribusi terhadap bagaimana performa anak baik di akademik maupun di kehidupan sosialnya. Salah satunya adalah bagaimana anak dapat membuat tujuan dan standart untuk dirinya sendiri, bagaimana mereka memonitor dan mengevaluasi proses kognitif dan perilaku mereka, serta mengetahui konsekuensi-konsekuensi yang akan dihadapinya pada saat kita bisa mendapatkan yang kita inginkan ataupun tidak, yang kesemuanya ini adalah merupakan elemen dari self regulation (Zimmerman dalam Ormrod, 2008). Bagaimana kemandirian anak dalam menghadapi kehidupannya di sekolahnya, bagaimana tanggung jawab yang dirasakan oleh si anak atas hasil prestasi studinya yang ia dapatkan, bagaimana anak menemukan motivasinya, kesemuanya itu merupakan bentuk-bentuk dari self regulation. Dalam penelitian oleh d'Ailly di tahun 2003 (dalam Guay, Ratelle, \& Chanal, 2008) ditemukan bahwa orang tua (terutama ibu) memiliki peran yang serupa dengan guru dalam pembentukan self regulation anak di sekolah. Selain itu dinyatakan juga bahwa orang tua selain guru/ pengajar merupakan sumber terhadap perkembangan motivasi anak di sekolahnya. Orang tua memegang peranan penting dalam perkembangan anak. Sejak kelahirannya, anak-anak dan orang tua memulai proses sosialisasi orang tua dan anak yang merupakan pembelajaran pertama keterampilan yang akan dibutuhkan si anak selama hidupnya (Walters \& Walters dalam Davidson \& Moore, 1996). Tugas orang tua adalah untuk menciptakan lingkungan atau situasi dan kondisi dimana anak dapat belajar perilaku bertanggung jawab dalam kehidupan sosialnya (Davidson \& Moore, 1996).

Dalam makalah kali ini, Penulis ingin menggali lagi bagaimana bentuk self Regulation pada anak yang underachiever, dan bagaimana juga peranan orang tua terhadap perkembangan self regulation ini. Penulisan ini diharapkan dapat membuka wawasan bagi para orang tua perihal pentingnya peranan mereka terhadap self regulation anak dan bagaimana pengaruhnya terhadap performa anak dalam pencapaian prestasi akademk mereka. Dalam penulisan ini, penulis menggunakan metode studi kepustakaan, dimana penulis menggunakan bahan yang bukan berasal dari 
sumber pertama sebagai sarana untuk memperoleh data atau informasi untuk menjawab permasalahan, melainkan dengan pengumpulan teori-teori maupun hasil penelitian yang sudah ada (Sarwono, 2006).

\section{PEMBAHASAN}

Untuk lebih memahami subyek dari penulisan ini, perlu kita lihat dahulu apa yang dimaksud dengan underachiever.

\section{Underachiever}

Underachiever adalah istilah yang diberikan kepada anak yang mengalami hambatan dalam perkembangannya (Spevak \& Karinch, 2006). Anak yang dinyatakan underachiever mungkin pada dasarnya merupakan anak yang kreatif, verbal yang baik, kemampuan matematis yang tinggi, namun mereka tidak sukses di sekolah (Rimm, 1986 dalam Episentrum, 2010). Istilah underachiever tidak terbatas pemakaiannya didalam dunia akademik saja, namun juga dalam situasi pekerjaan dan lainnya, dimana terdapat pengukuran hasil kerja. Dengan kata lain, underachiever adalah kondisi dimana seorang individu belum mampu untuk mengenali dan atau menggunakan kemampuan dirinya secara maksimal sehingga memperoleh performa yang tidak sesuai dengan standart atau yang diharapkan.

Menurut Peters (2000), karakteristik underachiever ditunjukkan dari terpenuhinya minimal 7 dari 13 kriteria yang ada yakni: (1) Nilai prestasi akademik tidak baik, (2) Menunda-nunda pengerjaan tugas sekolah, (3) Mengerjakan tugas jika ada hukuman atau diberikan reward, (4) Nilai-nilainya cenderung berbeda jauh dari teman sekelasnya (di bawah rata-rata kelas), (5) Suka ketinggalan barangbarang keperluang sekolah, (6) Lupa terhadap hal-hal penting seperti jadwal belajar, (7) Mengabaikan informasi penting dari sekolah, (8) Berpura-pura lupa terhadap pekerjaan rumah dan lebih menyukai melakukan kegiatan yang digemarinya, (9) Menyalin pekerjaan dan tugas teman, (10) Tidak ikut pelajaran meskipun tidak sakit, tidak masuk sekolah tanpa izin, (11) Memiliki rencana untuk membolos, (12) Tidak memperhatikan guru karena tidak mendapat perhatian walaupun ia memahami pelajaran yang diajarkan guru, dan (13) Menguji dan menantang peraturan-peraturan yang telah ada di rumah dan di sekolah.

Selain itu, Peters (2000) juga membagi underachiever ke dalam 6 kategori, antara lain:

\section{The If-Then Student}

Siswa ini adalah siswa yang menganut prinsip bila sesuatu penting untuknya, maka ia akan melakukannya. Namun bila sesuatu tidak penting untuknya, ia akan menunda atau menolak untuk melakukannya. Untuk mengatasi siswa dengan tipe ini maka orang tua harus mengubah strategi dengan mengarahkan anak ke jalur akademis yang benar.

\section{The Chameleon Student}

Siswa ini adalah siswa yang mampu beradaptasi terhadap harapan guru dan orang tua untuk berhasil di kelas dengan usaha seminimal mungkin. Siswa dengan tipe ini bertingkah laku baik dalam lingkungan yang memang menuntut untuk bertingkah laku baik. Namun bisa menjadi kasar dan tidak bertanggung jawab bila berada dalam lingkungan yang tidak menuntut tingkah laku baik. Siswa ini bukanlah anak yang tidak baik, mereka hanya mengambil keuntungan dari celah situasi yang ada. Untuk dapat mengatasi siswa ini maka dapat menerapkan strategi dengan mengantisipasi celah tersebut (jadwal tugas yang tidak jelas, guru yang tidak terorganisir) dan membuat rencana agar kebiasaan memanipulasi tersebut berkurang. Yakinkan guru untuk memeriksa tugas-tugas setiap hari sehingga orang tua mengetahui apa yang harus dikerjakan setiap hari. 


\section{Disorganized Student}

Siswa dalam kategori ini mengalami kesulitan dalam mengorganisir kegiatan belajarnya, meskipun dirinya terlihat untuk mengatasi kesulitan ini. Untuk dapat mengatasi siswa tipe ini, maka siswa harus belajar menerapkan sistem organisasi akademis yang realistis. Orang tua harus memotivasi secara eksternal dan menerapkan konsekuensi positif dan negatif secara konsisten.

\section{Manipulative Student}

Adalah siswa yang selalu berupaya menghindari tugas dengan berbagai cara, termasuk menipu orang-orang yang ada di sekitarnya atau memanipulasi tugas. Untuk mengatasi siswa tipe ini maka siswa harus menerima konsekwensi dari tindakan-tindakan manipulasinya, di mana ia harus mengejar ketertinggalan pelajarannya.

\section{The Here Today Gone Tomorrow}

Adalah siswa yang seringkali meninggalkan jam pelajaran tanpa sepengetahuan guru atau orang tuanya. Untuk mengatasi siswa tipe ini maka guru perlu memberikan lembar harian yang harus diisi dengan tandatangan guru setiap hari dan kemudian ditunjukkan pada orang tua. Komunikasi antara orang tua dan guru menjadi sesuatu yang sangat penting.

\section{The Rebellious Student}

Adalah siswa yang selalu melakukan perilaku untuk membuat orang lain jengkel, tanpa merasa bersalah atau bertanggung jawab dengan apa yang dilakukannya. Menerima semua hukuman dan menikmatinya, dengan tujuan untuk memberi kesan pada guru atau orang tua bahwa ia tidak dapat dipaksa untuk melakukan apa pun. Untuk mengatasi siswa tipe ini adalah dengan memberitahunya bahwa ada konsekuensi tertentu jika ia tidak mengikuti peraturan. Sebaiknya hal ini dilakukan secara konsisten di rumah maupun sekolah.

Setelah mengetahui siapa dan bagaimana perilaku underachiever, penting pula kita mengetahui apa yang dimaksud dengan self regulation, karena dalam makalah ini self regulation merupakan salah satu variabel yang ingin ditelaah.

\section{Self Regulation}

"The standart and goals we set for ourselves, the ways in which we monitor and evaluate our own cognitive processes and behaviors, ad the consequences we impose on ourselves for our successes and failures-all of these are aspects of self regulation.If our thoughs and actions are under our control, rather than being controlled by the people and circumstances around us, we are self-regulating individuals."

Zimmerman, 1998 (dalam Ormrod, 2008)

Dari pernyataan tersebut, dapat disimpulkan bahwa yang dimaksud dengan self regulation adalah kemampuan seseorang untuk melakukan kontrol atas pemikiran dan perilakunya dalam situasi dan kondisi yang sedang dihadapinya. Self regulation idealnya berkembang meningkat sejalan dengan perkembangan usia. Semakin besar usianya, berarti semakin tinggi tingkat proses kognitif pada individu tersebut, maka semakin baik pula self regulation-nya.

Menurut Bandura (1986, dalam Ormrod, 2008) self regulation terbentuk sejalan dengan pembelajaran perilaku yang dialami oleh seorang individu. Dalam pembentukan perilakunya, seorang individu akan mendapatkan penguatan maupun hukuman dari perilaku yang dihasilkannya. Dengan demikian, seorang individu belajar untuk memahami mana perilaku yang boleh dimunculkan dan mana yang tdak boleh dimunculkan. Dari kondisi tersebut membuat individu kemudian melakukan kontrol terhadap pengeluaran perilakunya. Hal ini telah membentuk self regulation pada individu tersebut. 
Terdapat 6 aspek dari self regulation, antara lain (Ormrod, 2008): (1) Menentukan standart dan tujuan pribadi, yaitu bahwa individu mampu membuat criteria sebagai dasar untuk melakukan evaluasi performa yang dihasilkan; (2) Regulasi emosi, yaitu proses dimana individu secara sadar dan intensive melakukan pengecekan terhadap kondisi emosi mereka dan melakukan pengalihan bilamana emosi tersebut dapat menyebabkan munculnya perilaku yang tidak produktif; (3) Instruksi diri, Kemampuan seorang individu untuk memberikan instruksi atau berbicara pada dirinya sendiri mengenai situasi yang sedang dihadapinya dan apa yang perlu dan tidak perlu dilakukannya; (4) Monitoring diri, Kemampuan individu utnuk mengamati dan mengingat perilakunya sendiri atau apa yang seharusnya dilakukan oleh dirinya sehingga dapat mencapai tujuannya; (5) Evaluasi diri, kemampuan individu untuk melakukan evaluasi terhadap performa atau perilakunya sendiri; (6) Selfimposed contingencies, kemampuan individu untuk menerima atau memberikan penguatan maupun hukuman terhadap dirinya sesuai dengan perilaku yang dihasilkannya.

Menurut Bandura dalam teori Reciprocal Causation , bahwa perilaku manusia dapat terbentuk sebagai hasil dari interaksi tiga komponen, yaitu person, behavior, dan environment (Feist \& Feist, 2006). Salah satu elemen dalam environment yang sangat lekat dengan perkembangan seorang individu adalah orang tua. Selama perjalanan hidup manusia, orang tua adalah faktor pertama yang ditemuinya, dan yang juga merupakan agen penting dalam pembentukan perilaku manusia tersebut.

\section{Parenting dan Self Regulation}

Menurut Hymes (dalam Davidson \& Moore, 1996) orang tua merupakan guru yang pertama dan yang terpenting bagi anak-anak.

"... The home is the laboratory of life, parents are the master teachers, and the child is the apprentice... Because rhe role of the parents is crucial to successful outcomes for the child..."

Moore (1985a) dalam Davidson \& Moore, 1996

Orang tua membutuhkan fleksibilitas dalam menghadapi stressor dalam keluarga nya dan juga adanya keseimbangan otonomi individual (adaptasi) dan juga hubungan emosional yang kuat antara ayah dan ibu, sehingga dapat mengembangkan peran orang tua yang sehat (Davidson \& Moore, 2006). Dalam Moilanen (2007) terdapat tiga perilaku orang tua yang memiliki pengaruh terhadap self regulation, yaitu kehangatan orang tua, kontrol secara psikologis dan kontrol terhadap perilaku. Dari hasil penelitiannya, Moilanen mendapati bahwa terdapat korelasi yang positif antara self regulation dengan perilaku orang tua yang hangat. Namun memiliki korelasi nengatif terhadap perilaku orang tua yang memberikan kontrol secara psikologis dan perilaku. Dengan demikian, dapat disimpulkan bahwa dibutuhkan kerjasama masing-masing orang tua untuk dapat menciptakan suasana yang hangat dalam pola asuh mereka terhadap anak-naka. Dengan demikian diharapkan dapat memberikan model yang baik/ positf terhadap anak sehingga mampu mengembangkan self regulation yang baik.

Untuk lebih jelasnya lagi mengenai jenis orangtua, berikut ini menurut Diane Baumrind (dalam Davidson \& Moore, 1996), pola asuh orang tua terhadap anak ada tiga macam, antara lain: pertama, The Authoritarian, dimana orang tua selalu melakukan kontrol dan memiliki banyak peraturan yang memiliki konsekuensi baik fisik maupun psikologis. Orang tua dengan tipe ini, memiliki bentuk perilaku memberikan pengarahan yang tinggi dan rendahnya tingkat afeksi dan kehangatan; kedua, The Permissive, Orang tua dengan tipe ini memiliki pemikiran bahwa anak sudah perlu belajar membuat keputusan mereka sendiri. Orang tua tipe ini tidak menggunakan hukuman atau kekuasaan mereka terhadap anak, melainkan dengan cara pemberian alasan dan manipulasi kondisi/ situasi, dalam melakukan kontrol terhadap perilaku anak; ketiga, The Authoritatve, Orang tua dengan tipe ini memberikan penekanan nilai pada komunikasi antara orang tua dan anak. Orang tua dengan tipe ini akan membuat diskusi dengan anak perihal apa yang dilakukan oleh anak dengan alasan-alasan 
atau latar belakangnya. Dengan metode ini membuat anak mampu mengembangkan kemauan untuk melakukan yang ingin dilakukannya dan sekaligus juga mampu untuk memberikan pertanyaanpertanyaan secara baik.

Dari tipe-tipe pola asuh yang ada, memang dapat kita lihat secara jelas bahwa pola asuh dengan tipe The Authoritative yang menjadi tipe orang tua ideal. Tipe Authoritative ini juga sejalan dengan hasil penelitian dari Moilanen dimana orang tua yang mampu memberikan suasana dan lingkungan hangat yang memiliki kesempatan yang besar bagi terbentuknya self regulation yang baik pada anak.

\section{Self Regulation dan Underachiever}

Self regulation jangka panjang maupun pendek, memiliki hubungan dengan performa di sekolah. Semakin tinggi level self regulation, maka semakin baik penyesuaian anak di lingkungan sekolah dan semakin baik pula performanya. Sebaliknya, rendahnya self regulation memiliki hubungan terhadap rendahnya performa di sekolah. Untuk demikian, pembentukan self regulation merupakan suatu hal yang penting untuk menjadi sorotan dari orang tua selama mendidik anak. Dengan tipe anak underachiever yang telah disebutkan dalam penjelasan mengenai underachiever dapat dilihat memang self regulation pada mereka masih dapat dikatakan kurang optimal. Bahwa pengaturan terhadap apa yang mereka lakukan lebih banyak berasal dari faktor eksternal diri mereka, entah itu adalah orang tua, pengajar, teman, bahkan masyarakat sosial.

Menurut penulis, self regulation yang berasal dari teori Bandura, yang mana merupakan hasil belajar, maka masih memiliki kemungkinan untuk dapat terus berubah, baik ke arah positif/ lebih baik ataupun ke arah negative/ lebih buruk. Hal ini tergantung pada bagaimana interaksi individu dengan lingkungannya, salah satunya adalah dengan keluarga inti atau orang tua.

Menurut Peters (2000) ada beberapa kesalahan pada perilaku orang tua terhadap anak underachiever, yang mana menurut penulis kondisi ini tidak akan membantu mengembangkan sef regulation mengarah pada pembentukan yang lebih baik, yaitu:

\section{Peace at Any Price}

Orang tua selalu berusaha menghindari konfrontasi dengan anaknya, dengan selalu memberikan apa yang menjadi keinginan anaknya. Dengan kata lain, asal anaknya tidak menangis atau berteriak karena meminta keinginannya dipenuhi, maka orang tuanya bersedia memenuhi apa keinginan dari anaknya. Kesalahan ini dapat mengakibatkan anak jadi tidak dapat mentoleransi perasaan frustrasi yang dialaminya dan menerapkan tingkah laku kasar di sekolah bila keinginannya tidak dituruti oleh teman-teman atau gurunya.

Anak yang tidak pernah belajar tingkah laku mengalah di rumah maka akan kesulitan untuk memiliki disiplin diri di sekolah. Oleh karena aturan yang ditetapkan di rumah tidak jelas, ambigu, mudah berubah maka anak tidak dapat bertoleransi dengan peraturan sekolah yang ketat. Kesalahan orang tua dengan selalu berusaha menghindari konfrontasi dengan anaknya membuat anak menerapkan taktik yang sama di sekolahnya. Anak akan merasa bila menampilkan tingkah laku penolakan, berteriak atau mengancam agar keinginannya dipenuhi orang tuanya di rumah, hal yang sama juga diterapkan di sekolah agar keinginannya dipenuhi. Jika anak menerapkan hal yang sama di sekolah dan muncul tingkah laku temper tantrum maka akan dijauhi oleh teman-temannya.

Orang tua yang menerapkan pola asuh dengan selalu berusaha menghindari konfrontasi dengan anaknya biasanya tidak menyadari bahwa sebenarnya mereka telah melakukan kesalahan tipe ini. Kesalahan ini sebenarnya menuntut harga yang mahal untuk dibayar. Dengan kesalahan ini anak 
dapat tidak memiliki dasar akademik yang kuat, konsep diri yang tidak baik dan coping skill yang tidak tepat.

\section{Leave it to the Teacher}

Ada dua tipe kesalahan "leave it to the teacher". Tipe pertama adalah orang tua yang berasumsi bahwa mereka akan dihubungi oleh guru jika ada masalah dengan prestasi anak. Jika orang tua ini dihubungi, barulah orang tua terlibat dan memberikan waktunya untuk memeriksa pekerjaan anak telah selesai dikerjakan atau belum. Orang tua seperti ini tidak tahu apa yang diharapkan oleh sekolah untuk anaknya setiap hari.

Tipe kedua adalah orang tua menyerahkan secara total tanggung jawab kepada guru dengan harapan agar guru juga mengatasi masalah-masalah yang dihadapi si anak. Menurut orang tua tipe ini, "no news is good news". Jika tidak ada berita maka itu adalah berita baik. Dengan tipe ini, anak tidak mendapat kesempatan untuk belajar bertanggung jawab ataupun memikirkan konsekuensi yang perlu ditanggung nya dari setiap tindakan maupun keputusan yang dilakukannya.

\section{Denial Dance}

Salah satu akademik yang terburuk adalah penyangkalan orang tua. Ada dua penyebab tingkah laku yang menyebabkan "denial dance”. Pertama, orang tua merasa bahwa perilaku anaknya baik seperti yang mereka harapkan. Orang tua merasa sudah memberikan aturan-aturan. Jika anak gagal, anak membuat kesalahan, atau mempertunjukkan masalah apa pun, ini mencerminkan arahan orang tua.

Kedua, kesalahan dalam denial dance adalah anak itu sendiri. Anak menyadari sikap defensif orang tuanya. Anak juga memiliki kemampuan berakting yang dapat membuatnya keluar dari situasi yang tidak menyenangkan, bukan menyelesaikan masalahnya.

\section{Doing the Homework for Your Child}

Pada tipe kesalahan ini, orang tua memberikan bantuan untuk mengerjakan pekerjaan rumah yang diberikan oleh guru. Hal ini membuat anak menjadi tidak dapat menolong dirinya sendiri dan selalu membutuhkan bantuan orang lain.

\section{Overcommiting}

Orang tua memberi kebebasan terhadap kegiatan di luar sekolah. Anak terlalu banyak mengikuti les atau tambahan pelajaran setiap harinya. Seperti halnya orang dewasa yang memiliki jadwal yang padat. Akibatnya ketika di malam hari anak mengalami kelelahan sehingga waktu yang seharusnya digunakan untuk mengerjakan pekerjaan rumah tidak dapat digunakan secara maksimal.

\section{Unreasonable Expectations}

Orang tua memiliki harapan yang berlebihan pada anak. Hal ini dapat menurunkan harga diri anak. Perbandingan antara saudara terkadang membuat orang tua tidak menyadari kemampuan anak. Hal ini dapat membuat anak berusaha terlalu keras sehingga dia merasa tidak mampu meraih prestasi maksimal. Kondisi ini dapat menyebabkan anak memiliki tuntutan yang tidak realistis terhadap dirinya dan memiliki tingkat kecemasan aygn tinggi atau sebaliknya menjadi tidak memiliki motivasi untuk pencapaian apapun. Self Concept pada anak juga dapat terpengaruh. 


\section{PENUTUP}

Pembentukan perilaku pada anak dimulai sejak usia kanak-kanak dan berlanjut hingga usia yang tidak dapat ditentukan. Hal ini disebabkan karena setiap individu memiliki kemampuan untuk belajar sesuai dengan rangsangan dari lingkungannya, termasuk orang tua. Ada banyak hal yang dilakukan oleh setiap orang baik disadari maupun tidak disadari yang memberikan efek pembentukan regulasi diri pada orang lain. Seperti misalnya yang dikatakan oleh Dr. Ruth Peters (Peters, 2000) terdapat 6 pola perilaku orang tua yang dapat memberikan dampak terhadap perilaku anak sehingga mereka memiliki kecenderungan untuk menjadi underachiever. Orang tua selalu ingin yang terbaik bagi anak. Hanya saja terkadang itu bercampur dengan bagaimana supaya semuanya menjadi mudah bagi si anak. Hal ini menyebabkan berkurangnya atau bahkan hilangnya esensi pembelajaran bagi si anak, yang dapat menyebabkan anak menjadi bergantung pada orang tua/ orang lain.

Dengan pembentukan perilaku dimana seorang anak selalu mendapatkan bantuan dari orang tuanya dalam mengerjakan tugas/ kewajibannya (seperti dalam kesalahan orang tua nomor 4) menyebabkan anak memiliki daya juang yang rendah dalam menghadapi tantangan dan atau selalu mengharapkan bantuan dari orang lain. Kondisi yang serupa dapat terjadi pula dengan kesalahan orang tua nomor 2, dimana orang tua meletakkan tanggung kawab kepada pihak institusi pendidikan. Hal ini menjadi pembelajaran bagi anak, bahwa bukan kewajiban pribadinya terhadap proses dan pencapaiannya melainkan insititusi/ orang lain. Dan hal lainnya dalam kesalahan orang tua menurut Dr. Ruth Peters (Peters, 2000) yang memberikan dampak signifikan terhadap bagaimana anak mampu bertanggung jawab terhadap dirinya dan mengatur kehidupannya sendiri. Dampak inilah yang dirasakan oleh anak-anak underachiever di sekolah maupun perguruan tinggi. Apabila kondisi ini tidak disadari dan mendapatkan kerjasama dari orang-orang yang terkait, seperti orang tua, untuk memperbaiki keadaan, maka kondisi ini akan bertahan lama hingga di dunia kerja.

Untuk itulah tinjauan teori ini dibuat, untuk memberikan referensi kepada pembaca, sehingga dapat melakukan evaluasi diri mengenai apa yang telah dilakukan maupun apa yang telah terjadi dalam hidupnya, sehingga dengan mengetahui hal tersebut dapat melakukan langkah-langkah perbaikan. Dan untuk pembaca juga diharapkan dapat lebih sadar terhadap efek dari perlakuan yang diberikan kepada orang lain.

\section{DAFTAR PUSTAKA}

Davidson, J.K., \& Moore, N.B. (1996). Marriage and family: change and continuity. Massachusetts: Allyn and Bacon.

Episentrum. (2010, September 3). Underachievement. Retrieved Februari 15, 2011, from Episentrum, Psikologi (Psychological Assessment, Counseling):

http://episentrum.com/artikel-psikologi/underachievement/

Feist, J., \& Feist, G. J. (2006). Theories of personality. $6^{\text {th }}$ ed. New York: McGraw-Hill.

Guay, F., Ratelle, C. F., \& Chanal, J. (2008). Optimal learning in optimal context: the role of selfdetermination in education. Canadian Psychology Vol 49 No 3, 233-240. 
Moilanen, K. L. (2007). The Adolescent Self-Regulatory Inventory: The Development and Validation of a Questionnaire of Short-Term and Long-Term Self-Regulation. J Youth Adolescence , 835848.

Ormrod, J. E., (2008). Educational psychology: developing learners. $6^{\text {th }}$ ed. NJ: Pearson Education, Inc.

Peters, R. (2000). Overcoming underachieving. NY: Broadway Books.

Sarwono, J. (2006). Metode penelitian kuantitatif dan kualitatif. Yogyakarta: Penerbit Graha Ilmu.

Spevak, P.A., \& Karinch, M. (2006). Empowering underachievers. NJ: New Horizon Press. 